\title{
HISTÓRIA E HISTORIOGRAFIA: IBN AL-ATHĪR, O LUGAR E A FUNÇÃO DA HISTÓRIA NA SÍRIA DO SÉCULO XIII ${ }^{1}$
}

\author{
Emily Fonseca de Souza ${ }^{2}$
}

\section{HISTORY AND HISTORIOGRAPHY: IBN AL-ATHĪR, THE PLACE AND FUNCTION OF HISTORY IN SYRIA IN THE $13^{\mathrm{TH}}$ CENTURY}

\begin{abstract}
Resumo: Apesar de não constar entre os saberes tradicionais, a História possui uma função fundamental nas sociedades mulçumanas medievais. Este artigo pretende apresentar o célebre historiador islâmico Ibn al-Athīr, seu fazer histórico e discutir a concepção de sua mais importânte obra, o Kitāb al kāmil fí l- ta'rīhn, e sua função enquanto conselheira real.
\end{abstract}

Palavras-chave: Historiografia Árabe, Ibn al-Athīr, Cruzadas, História do Oriente Próximo

\begin{abstract}
Although not among on the traditional knowledge, History has a fundamental function in medieval Muslim societies. This article intends to present the celebrated Islamic historian Ibn al-Athīr, his historical record and discuss the conception of his most important work, Kitāb al kāmil fi l- ta'rīh, and his role as royal counselor.
\end{abstract}

Keywords: Arabic Historiography, Ibn alAthīr, Crusades, Near Eastern History

\section{O LUGAR DA HISTÓRIA NAS SOCIEDADES MUÇULMANAS MEDIEVAIS.}

Admite-se que a ideia de história seja denotada em árabe pelos termos $a h b \bar{a} r^{3}$ - relatos, informações - e ta'rīh ${ }^{4}$ - datação, cronologia, era ${ }^{5}$. Ahbār, corresponde a história no sentido de estória (do inglês story ${ }^{6}$ ) ou seja, não designa em acontecimento pretérito. Trata-se tão somente da transmissão de uma observação direta, visual, ou de um relato de um testemunho que se crê verídico; Ta’rīh, por sua vez, é uma palavra que não surge ${ }^{1}$ Este artigo é uma versão modificada de um capítulo apresentado em minha dissertação de mestrado em História Social pela FFLCH - USP: A unificação da Síria e o jihād de Nūr ad-Dīn na crônica Kitāb al-Kāmil fi l-ta'rīkh, de Ibn al-Athïr, defendida em 2016.

${ }^{2}$ Mestre em História Social pela Faculdade de Filosofia, Letras e Ciências Humanas da Universidade de São Paulo. Atua como pesquisadora em ciências humanas e sociais no Centro de Pesquisa e Formação do Sesc - SP. Pesquisa discursos de jihād na historiografia árabe. http://buscatextual.cnpq.br/buscatextual/visualizacv.do?id=K4306974Y7. E-mail: fonsecaemily@gmail.com

${ }^{3}$ Habar - ahbār (pl.)

${ }^{4}$ Para esta pesquisa, utilizarei a padronização sugerida por Safa Abou-Chahla Jubran, em Para uma romanização padronizada de termos árabes em textos de Língua Portuguesa, in Tiraz (USP), pp. 17-30, 2004.

${ }^{5}$ ROSENTHAL, Franz. A History of a Muslim Historiography. Netherlands: E.J Brill. Leiden, 1968. Ele discute a possível origem etimológica das duas palavras. Apesar de uma origem não clara, ele sugere que a primeira derive do Acadio habaru, enquanto a segunda apresenta um grande número de possibilidades de origens, desde derivações do semítico até os dialetos norte e sul arábicos. p. 12 et seq.

${ }^{6}$ Encontramos na Língua Portuguesa a palavra estória, que carregaria este mesmo sentido. Porém, os dicionários não recomendam a distinção entre história e estória. Neste sentido, preferi utilizar a comparação realizada por Rosenthal (1968, p. 11), em língua inglesa, mantendo a coerência do raciocínio. 


\section{capítulo de dissertação}

junto com o 'Islām, mas, sim, no segundo século da Hégira, e refere-se a trabalhos datados. Daí, a palavra ta'rīh passa a ser correntemente utilizada, desde o século IX, para designar História em um sentido amplo (Franz Rosenthal, 1968, p.8 e seq.). A partir do século XII, embora ambos os termos coexistam, ta'rīh é usado em textos acadêmicos. ${ }^{8}$

Para o historiador orientalista alemão Franz Rosenthal ${ }^{9}$, a relação estabelecida entre a palavra ta'rīh e o conceito de História que adotamos é a associação que se estabelece apenas graças a um vínculo semântico. Isto é, o conjunto de noções evocadas pela palavra ta'rīh é diferente daquele sugerido pela nossa palavra História e, mesmo quando elas se encontram, as implicações sobre o nosso conceito - produto de um historicismo moderno - configuram-no para além do que a mentalidade muçulmana compreende por história (Rosenthal, 1968, p. 15). Há, então uma discrepância no entendimento semântico e ideológico de história e que influencia o tratamento do objeto histórico e a visão que teremos dele.

A partir destes mesmos termos que denotam a ideia de história em árabe, o historiador Abdsselam Cheddadi ${ }^{10}$ propõe outra análise, que relaciona as questões de memória e história ${ }^{11}$, entendendo como memória aquilo que um grupo ou uma sociedade retém e elabora de seu passado. Neste sentido, uma concepção de história essencialmente plural e, acima de tudo, informativa, sobrepõe-se a uma concepção da história como cronologia e datação. Além disso, para ele, a dupla designação - aḩbār e ta'rīh - indica uma relação entre memória e história, entre o espalhamento das memórias particulares e setoriais e a aspiração de uma memória unificada (Cheddadi, 1991, p. 30 et seq.).

Ora, o conceito de história para essa sociedade está diretamente ligado à fé islâmica. O 'Islām instaura, desde o seu início, atividades da prática historiográfica a fim de organizar a memória de um texto (Alcorão) e de um homem (Muhammad ${ }^{12}$ ) - através dos $a h \bar{a}^{2} d \underline{t}^{13}$, da Sìra e Maǵäzi - em torno dos quais toda a sociedade e cultura islâmica se organizam, dando

\footnotetext{
${ }^{7}$ No medievo ocidental, estes elementos são pouco diferenciados, portanto, intercambiáveis. A utilização de vocábulos como Chronicon, Históra e Gesta são utilizadas de forma indiscriminada nos textos do ocidente.

${ }^{8}$ Importante destacar que o termo ta'rīh não aparece na literatura pré-islâmica, tampouco em toda a extensão do Alcorão.

${ }^{9}$ A obra de Rosenthal, ainda hoje, é considerada um trabalho essencial no estudo da historiografia muçulmana e muitos orientalistas ainda consideram-na o melhor e mais completo trabalho de análise sobre a história da historiografia islâmica.

${ }^{10}$ CHEDDADI, Abdesselam. A l'aube de l'historiographie arabo-musulmane: la mémoire islamique. In: Studia Islamica, $\mathrm{N}^{\circ} 74$ (1991), pp. 29-41.

${ }^{11}$ Enquanto a obra de Rosenthal carrega a herança de uma concepção de história do século XIX, e realiza uma análise filológica e descritiva do desenvolvimento da historiografia muçulmana, Cheddadi procura realizar uma análise da história da historiografia muçulmana que leve em conta a questão da memória discutida pela escola dos Anales, principalmente, por Jacques Le Goff.

${ }^{12}$ Ainda que haja um polo da memória islâmica na pessoa de Muhammad, a vida do profeta não é sacralizada. Isto é, nenhum momento de sua vida foi integrado a algum tipo de objeto de culto ou ritual, como é feito no cristianismo com Jesus.

${ }^{13}$ Hadit - ahāāiț (pl.)
} 


\section{capítulo de dissertação}

origem a outras memórias, isto é, memórias árabes, políticas, etnográficas, culturais, etc, todas derivadas do nascimento do 'Islām (Cheddadi, 1991. p. 34). É através da Palavra Revelada a Muhammad que o 'Islām inscreve o homem árabe dentro de um contexto histórico definido, com início e fim bem estabelecidos ${ }^{14}$. Deste modo, 'Islām e história são sinônimos, como mostra o Alcorão quando diz: "E não vos fez constrangimento algum, na religião: a crença de vosso pai Abraão. Ele vos nomeou moslimes, antes [de Abraão] e, agora neste [Alcorão], para que o Mensageiro seja testemunha de vós, e vós sejais testemunhas da humanidade" (Alcorão, XII, 78) ${ }^{15}$. A partir deste momento, o homem está inscrito num mundo que começa muito antes dele, com a Criação, e que acabará no dia do Juízo Final. Um futuro no qual ele e futuras gerações estão circunscritas. Assim, ao ter o seu fim pré-determinado pelo Dia do Julgamento, o homem passa a avaliar as ações do presente, porque elas serão cobradas na prestação de contas que os aguarda após a morte. Assim, a ação humana assume, então, uma aparência permanente e constitui um incentivo definitivo para registrar e memorar o passado.

A crítica que Rosenthal faz a essa concepção é que o "futuro determinado cria uma desvalorização da história como reflexão sobre os fatores atuais ao homem e a sua influência na vida humana [...] desestimulando o pensamento histórico" (Rosenthal, 1968, p.25). Contudo, o trabalho de análise da obra de Ibn al-Athīr, realizado aqui, mostra o contrário: mesmo inserido num contexto histórico determinado, o historiador muçulmano possui uma grande preocupação em explicar os eventos pelas suas condições temporais e políticas. Preocupação que Ibn Haldūn também demonstrará, uma vez que ele observa fenômenos sociais para, ao fim, chegar a leis universais que, segundo ele, regem o desenvolvimento das civilizações (Richard Max de Araújo ${ }^{16}, 2007$ p.55).

Ibn al-Athīr trata da relação político-religiosa. Isto é, abaixo de um Deus, que dirige o curso de toda a humanidade, impõem-se uma explicação temporal e política para os eventos, aquela da responsabilidade individual do soberano. Ao analisar as sucessões dinásticas em que o poder não passa para um sucessor direto, e sim a um ramo colateral - como foi com os Omíadas, Abássidas, Seljúcidas, etc -, Ibn al-Athīr justifica:

Tenho lido e visto muitos eventos da história islâmica que podem ser documentados de forma confiável. Eu tenho visto, no caso de muitos que iniciaram uma dinastia, que o poder é transferido de sua prole imediata para

\footnotetext{
${ }^{14}$ Entretanto, Cheddadi (1991, p.40) afirma que o Alcorão nunca figurou entre os objetos que se encarregam do ta’rīh, ainda que fosse visto como a única fonte verdadeira de informações sobre a Criação e a história dos profetas.

${ }^{15}$ Colchetes explicativos nosso. Essa passagem também pode atribuir um caráter anacrônico ao 'Islām, na medida em que este só existe, como tempo histórico, com a Revelação ao Profeta. Mas a passagem caracteriza os patriarcas como muçulmanos muito antes do 'Islām, em si, existir. Poderíamos pensar, igualmente, numa diferença entre tempo histórico e tempo mítico.

${ }^{16}$ ARAÚJO, Richard Max de. Ibn Khaldun: Idéia de Decadência dos Estados. São Paulo: Humanitas Editorial; Fapesp, 2007
} 


\section{capítulo de dissertação}

outra família e parentes. [...] Foi assim para as maiores dinastias do 'Islām. Por medo de ser muito prolixo, não daremos outros exemplos. Quanto à causa disso, penso que o primeiro de uma dinastia to $\mathrm{ma}$ medidas extre mas ${ }^{17}$ e se coloca no poder, enquanto os corações de seus antecessores estão profundamente ligados ao poder. Por isso, Deus, como punição para eles, nega o poder ao seus descendentes e àqueles que agem assim. (Ibn al-Athīir ${ }^{18}, 2010$. p.178-179.)

A princípio, pode-se acreditar que a declaração acima não condiz com a análise propriamente política almejada por Ibn al-Athīr, visto que o autor acaba por colocar em última instância, Deus, um ente metafísico, no controle da situação. Mas, a questão aqui é outra: essa fala remete à reflexão sobre os mecanismos de transmissão de poder e contém algo da reflexão levada mais tarde por Ibn Haldūn, segundo a qual o poder comporta os germes de sua própria degeneração. Entretanto, Ibn Haldūn realiza essa reflexão sobre toda a sociedade, sobre os povos e não somente sobre os príncipes, como é o caso de Ibn al-Athīr. Para nosso historiador, estão na pessoa do soberano, e não na vontade de Deus, as decisões e consequências de cada ação para a manutenção do poder de uma dinastia e seu governo.

Ademais, o estudo do passado - logo, da história - tem uma importância ética e moral na medida em que as predicações e a Palavra Revelada estimulam a importância de relacionar os eventos passados da sociedade com advertências para a humanidade. Desta forma, o conhecimento histórico serve de aconselhamento e exemplificação moral aos crentes, como diz o Alcorão:

E não caminharam na terra, para olhar como foi o fim dos que foram antes deles? Aqueles foram mais veementes que estes, em força e vestígios deixados na terra; então, Allāh apanhou-os, por seus delitos, e nao tiveram contra o castigo de Allāh, protetor. ${ }^{19}$ (Alcorão, XL, 21)

As instruções do Alcorão para viajar sobre as terras e ver o que se abateu sobre as nações e civilizações passadas, reforçam a compreensão dos muçulmanos do conceito de história e a decisão de registrar esse passado. 0 objetivo do estudo da história é, também, o estabelecimento da justiça e da boa conduta moral.

É a partir da predicação prófética que o árabe acessa a sua consciência histórica. A históriografia é, primeiramente, filha da Tradição, isto é, do recolhimento dos gestos do Profeta e de seus acompanhantes. A Sunna constituiu o seu corpus através da metodologia do 'isnā $d^{20}$, que é a atestação da autenticidade de uma informação pelo valor da cadeia

\footnotetext{
${ }^{17}$ D.S.Richards (2010. p.179) aponta que interpretou "yukthir, enquanto outros leem yukthir al-qatl ("matar muitas pessoas")". Micheau (2007. P. 100), por exemplo, ao fazer esta citação, escreve "multiplica as execuções".

${ }^{18}$ IBN AL ATHĪR. IZZ AL DIN. The Chronicle of Ibn al Athir for the Crusading Period from al Kamil I l-ta-rikh. Part 2: The Years 541-589/1146/1193: the Age of Nur al Din and Saladin. Crusade Texts Translations, 15. Trad. D.S. Richards. Ashgate. Surrey, 2010.

${ }^{19}$ Destaques do tradutor.

${ }^{20}$ Asānīd (pl.)
} 
de transmissores. Assim, o Hadit ${ }^{21}$ e, consequentemente, a historiografia, apoiar-se-ão no 'isnād para compor suas obras ${ }^{22}$.

É através da Sunna que organizam-se os outros saberes, dispersos em ciências exegese, as ciências das leituras corânicas, o direito, a gramática, etc. A historiografia muçulmana esteve sempre unida ao desenvolvimento geral do conhecimento no 'Islām, e a posição do conhecimento histórico na educação muçulmana exerceu uma influência decisiva no nível intelectual da escrita histórica. Mas, a ausência da história como uma das ciências do corpus oficial ${ }^{23}$ levou historiadores como Rosenthal (1968, p. 194) a afirmar que "a historiografia, nunca foi um dos fatores determinantes das correntes da vida intellectual muçulmana" e delegar à história uma posição na sociedade muçulmana apenas como "um assunto ocasional de formação dos meninos na escola" (1968, p. 45).

De fato, na origem do 'Islām, a historiografia nasce do seio do Alcorão, assim como a Sunna. Entretanto, a partir do século VIII, a Sunna se transforma num gênero autônomo, ocupando um lugar ao lado do Alcorão. Instala-se uma disposição concêntrica de saberes, em que o Alcorão está no centro e, ao redor, os outros saberes, criando uma escala na importância das ciências e saberes. A historiografia passa a ocupar o espaço da literatura de $A d a b^{24}$, geralmente definido como "as coisas adequadas para conhecer e agir de acordo"25. O conhecimento, ou melhor, o conjunto de temas que o homem deveria possuir se quisesse acessar a corte. Era este conjunto de conhecimento, do qual a história fazia parte, que permitiria ao seu detentor circular nas mais altas esferas da sociedade. 0 historiador André Miquel $^{26}$ afirma que, neste sentido "a cultura, não é somente um saber, ela é também, um passaporte [...]" (Eddin Bencheik; Miquel, 1992, p.

\footnotetext{
${ }^{21}$ Corpus das palavras e atos do Profeta. O historiador Abdesselem Cheddadi (1991, p. 41) afirma que este corpus "escapa do âmbito da história". Apesar de fornecer algumas informações históricas, este não é seu principal objetivo, mas sim constituir os precedentes da prática jurídica. 0 ta’rīh segundo Cheddadi jamais reivindicará a Sunna como um de seus ramos. Ao contrário do que ocorrerá com as biografias do Profeta.

${ }^{22}$ Ibn al-Athīr, por exemplo, faz uma menção a esta cadeia de trasnmissão em sua obra, quando cita a morte de Ibrāhīm ibn Nabahān, em 1149, dizendo que ele tinha sido pupilo de al-Ġazālī e al-Šāšì e que transmitiu o digesto "As Duas Genuinas Coleções", de al-Ḥumaydī, direto do autor.

${ }^{23} \mathrm{Na}$ classificação herdada da tradição filosófica grega, adotada pelos letrados árabes helenizados, a história não possuía nenhum lugar de destaque. Somente no século X, Ibn al-Nadīm apresenta em sua obra chamada Fihrist, uma categoria específica aos historiadores, genealogistas, biógrafos. Na obra Islamic Historiography. Cambridge University Press. 2003, Chase Robinson mostra que, o capitulo especifico que o autor trata da historiografia, o terceiro de dez capítulos, ocupa cerca de vinte por cento de todo o livro, listando cerca de 100 autores. (p. 5 et seq)

${ }^{24}$ A palavra pode ser entendida, entre outras traduções, como decoro, boa conduta, bons modos, etc. Adoto esta tradução, utilizada por Mamede Mustafa Jarouche na tradução da obra Kalīla e Dimna (p. XXXIV), de Ibn Almuqaffa'(IBN ALMUQAFFA', Kalīla e Dimna. Org. Trad. Introdução e notas Mamede Mustafa Jarouche. São Paulo; Martins Fontes, 2005).

${ }^{25}$ Hämeen-Anttila, Jaakko. "Adab a. Arabic, early developments." Encyclopaedia of Islam, THREE. Edited by Kate Fleet, Gudrun Krämer, Denis Matringe, John Nawas, Everett Rowson. Brill Online. 2015. Referência. http://www.brillonline.com/

${ }^{26}$ BENCHEIKH, Jamel Eddine. MIQUEL, André. D’Arabie et D'Islam. Paris: Éditions Odile Jacob, 1992
} 
42). A partir desta hierarquização de saberes, em que qualquer conhecimento que não tivesse relação direta com o religioso teria um grau de desvalorização, na medida em que ele é o coração dessa estrutura científica, medir a importância dos textos que objetivavam narrar os feitos passados apenas por uma classificação metodológica de saberes pode ser um erro. Então, ao propor uma avaliação da importância desses textos a partir do seu lugar na própria dinâmica social e política da sociedade, percebe-se que seu lugar é, na verdade, de grande destaque.

As três principais categorias sociais interessadas na leitura dos livros de história, como mostra Hourai Touati ${ }^{27}$, eram os príncipes, as cortes e os letrados: “Os primeiros porque a história revela a arte de governar, o segundo, pois são tributários de um modelo de sociabilidade e o terceiro por uma prática do saber" (Touati, 2007, p. 13). Mas os livros de história não estão restritos a essas três esferas, pois eles estavam disponíveis a quem se interessasse como instrução ou entretenimento, fosse através das leituras privadas ou públicas - esta última não necessitando da prerrogativa da alfabetização como condição de acesso ao conhecimento. Dessas três esferas da sociedade, leitoras das obras historiográficas, gostaria de destacar as duas primeiras, os príncipes e a corte, pois acredito que a leitura dessas obras para as classes letradas se explica pela própria prática do conhecimento, enquanto a história possui, para as outras duas, uma função política e social muito importante na sociedade islâmica.

A historiografia cronística é, antes de tudo, um instrumento de construção de discurso que fundamenta a memória dos governos. Além disso, é uma aliada do príncipe na arte de governar, e Ibn al-Athīr, no Kāmil, deixa claro, na introdução, que a obra é, de fato, uma história para príncipes, pois:

Se os príncipes e aqueles que detêm o poder de ordenar e de proibir
conhecem as biografias dos tiranos e dos opressores e veem que elas estão
consignadas nos livros que as pessoas fazem circular e se transmite de geração
a geração, eles podem constatar as consequências de tais comportamentos: má
reputação, eventos detestáveis, países arruinados, sujeitos ceifados pela morte,
riquezas desaparecidas, costumes corrompidos. Então, eles desaprovam tais
condutas, evitando-as e se esquivando delas. Se eles querem as belas biografias
dos governos justos e a boa reputação que os segue após sua morte, assim
como a prosperidade desses países e reinos e a abundância de seus bens, eles
aprovam sua conduta, querem imitá-la de maneira constante e abandonam o
que é contrário. (Ibn al-Athīr, apud Françoise Micheau ${ }^{28}, 2007$, p. 93)

A historiografia cumpre o papel de uma espécie de manual de governança, além de ser um dos instrumentos do cumprimento da ordem do Alcorão, de buscar no passado os exemplos dos governos. Assim, o príncipe deve estar cercado pelos livros, aprender e instruirse, para tomar as melhores decisões. A historiografia cumpre a função de conselheira Real.

${ }^{27}$ TOUATI, Houari. Pour une histoire de la lecture au Moyen Âge musulman: à propôs des livres d'histoire. In: Studia Islamica. $N^{\circ}$ 104/105. Chroniques Medievales: Temps, Narration, Usages (2007), pp. 11-44.

${ }^{28}$ MICHEAU, Françoise. Le Kitāb al kāmil fī l-tā'rīkh d'Ibn al-Athīr: Entre chronique et histoire. In: Studia Islamica. $N^{\circ}$ 104/105. Chroniques Medievales: Temps, Narration, Usages (2007), pp. 81-101. 


\section{capítulo de dissertação}

Esse aconselhamento e instrução aconteciam desde a juventude do príncipe, através de seus tutores, escolhidos na própria corte do Califa. 0 historiador muçulmano Mas'ūdī, em sua obra prima As Pradarias de Ouro, relata o percurso educacional do jovem príncipe al-Mahdī, filho do califa al-Manșūr, no sentido de prepará-lo para exercer o califado. Segundo o autor, o preceptor tinha por missão "lhe instruir nas jornadas célebres dos Árabes, na boa educação, ensinar-lhe sobre história e recitar-lhe suas poesias" (Mas 'ūdī, apud Touati. 2007, p.20). 0 então futuro califa al-Rāḍi teve como tutor o prosador al-Sulī, que deixou por escrito o testemunho do caminho percorrido para a educação do jovem mostrando que existe um percurso na educação desses jovens príncipes que começa pelas ciências "profanas" e que a língua e a história possuem um grande destaque : “[... Eu inspirava em cada um [al-Rāọī e seu irmão] o amor pela ciência e comprei para eles um belo lote de obras de direito, poesia, filologia e história[...] cada um deles se fez uma biblioteca e estudavam, sob minha direção, história e poesia”. E, somente após isto, é feito o estudo da Sunna: "Depois, eu disse-lhes que o hadit era uma ciência mais digna para eles e que ela merecia que eles começassem a estudá-la" (al-Sulī; Mas' ūdī, apud Touati, 2007, p. 22).

Para a corte, por sua vez, a aquisição desses saberes está ligada a condição social de cortesão. Nesta camada da sociedade, a distinção entre os homens dá-se no âmbito do saber. Vimos acima que os tutores dos califas eram escolhidos na corte. Ora, a escolha dava-se entre aqueles que possuíam os melhores conhecimentos - da Sunna às ciências profanas. Quem se destacava neste âmbito se aproximava mais do governante, como tutor, conselheiro, pessoa de confiança. Logo, o conhecimento não era uma forma de postular o poder, mas de influenciá-lo. Mahmood ul-Hasan ${ }^{29}$, ao apresentar o pai de Ibn al-Athīr, nos mostra um exemplo de como o conhecimento é um fator determinante nesta sociedade:

Ele pertencia à tribo Šācbān. Talvez seus antepassados imediatos não se distinguiram em qualquer campo da aprendizagem, da política e da administração, caso contrário, livros históricos conteriam algumas informações sobre eles. É muito provável que Athīr al-Dīn tenha adquirido proficiência em temas tradicionais, por exemplo, hadit, fiqh e adab e foi competente o suficiente para ensinar a seu filho a literatura do hadit. (Ul-Hasan, 2005. p.41)

A ausência de informações dos antepassados da família de Athīr al-Dīn está diretamente relacionada às suas posses intelectuais. Além disso, é importante notar a presença dos livros de história como o receptáculo da imortalidade. Ainda, as qualidades de "educado, inteligente, sábio, honesto" e de "homem leal", são utilizadas para justificar a proeminência da carreira de Ibn al-Athīr, quando ele passa a ter contato com os homens de 'Imād al-Dīn Zinkī (Ul-Hasan, 2005, p.41).

\footnotetext{
${ }^{29}$ UL-HASAN, Mahmood. Ibn al-Athīr. An Arab Historian. A Critical Analysis of His Tarikh al-Kamil and Tarikh al-Atabeca. New Deli: Northern Book Centre, 2005.
} 


\title{
capítulo de dissertação
}

Mesmo nas narrativas ficcionais, a característica de distinção através do domínio de saberes monstra o quanto o conhecimento era fundamental nesta camada cortesã da sociedade. Na narrativa das Mil e Uma Noites ${ }^{30}$, a personagem Šahrāzād nunca é descrita fisicamente, mas existe uma descrição intelectual da filha do vizir-mor de Šāhriyār:

\begin{abstract}
Šahrāzād, a mais velha, tinha lido livros de compilações, de sabedoria e de medicina; decorara poesias e consultara as crônicas históricas; conhecia tanto os dizeres de toda gente como as palavras dos sábios e dos reis. Conhecedora das coisas, inteligente, sábia e cultivada, tinha lido e entendido. (Mil e uma noites [...], 2006, p. 49)
\end{abstract}

No decorrer da obra entendemos que é a inteligência e astucia da personagem que a mantém viva e que seu papel na narrativa é, também, o de conselheira. Ao expor as diversas narrativas ao rei, Šahrāzād, propõe entretenimento, mas suscita, ao mesmo tempo, uma reflexão sobre as posturas dos homens de poder das narrativas, consequentemente, a postura d o p r o p ri o Šāhriyār. Portanto, uma disciplina que é apresentada em destaque nos estudos da corte e como obrigatoriedade no currículo cientifico dos governantes - como uma apropriação da experiência dos antepassados não pode ser relegada à uma posição menor, como Rosenthal faz.

Finalmente, outra característica no tratamento da historiografia pela sociedade árabe que demonstra o seu prestígio é a forma de transmissão das obras históricas. Ela segue a mesma regra de ritualização estabelecida pelos ulemás para outras obras consideradas maiores, como o direito, a gramática e a filologia. As atestações de leitura e certificados de audição - samā' - deveriam constar nos manuscritos e eram redigidas tanto pelos mestres quanto pelos discípulos ${ }^{31}$. Elas garantiam a legitimidade da obra, além de um controle da transmissão dos textos. ${ }^{32}$ Assim, ao seguir esta mesma prática de controle sobre um conteúdo e sua divulgação, aplicada às "ciências maiores", a historiografia mostra que atua no âmbito que diz respeito à legitimação de uma unidade

\footnotetext{
${ }^{30}$ ANÔNIMO. Livro das Mil e Uma Noites, Volume I: ramo sírio. (Introdução, notas, apêndices e tradução do árabe: Mamede Mustafa Jarouche). São Paulo: Globo, 2006.

${ }^{31}$ Fosse por transmissão oral direta dos mestres - autores - e copiada pelos ouvintes, que recebiam uma certificação e poderiam configurar na lista de transmissores dessa da obra se seguissem o mesmo modus operandi; ou, pela transcrição de uma obra a partir de um manuscrito autêntico. A forma de transmissão era determinada pelo autor da obra, que poderia exigir a transmissão integral ou não de sua obra, por exemplo. Touati (2007, p. 35) afirma que Ibn Abī Khuthayama autorizou somente copias integrais de sua obra, durante sua vida.

${ }^{32}$ Com a criação da indústria do papel e a mercantilização dos livros, esse controle tornou-se quase impossível. Muitos ulemás passaram a criticar a o ato de leitura individualizado das obras. Para alguns, como mostra Touati (2007, p.42), esse tipo de leitura só poderia ser realizado por sábios ou por aqueles que fossem educados por mestres qualificados. É interessante perceber que essa crítica à uma leitura fora das instâncias de controle foi realizada também pela Falsafa, com Ibn Rušd (Averróis) em seu Livro do Discurso Decisivo, quando critica a interpretação do Alcorão feita por aqueles que não possuem as prerrogativas necessárias para realizá-las. Para ele, somente os filósofos, aqueles com qualidades intelectuais superiores, poderiam ter acesso às interpretações do Alcorão. (AVERROES. Le livre du discours décisif. Trad. Marc Geoffroy. GF Flamarion, 1996. Pp. 145 et seq).
} 


\section{capítulo de dissertação}

de memória coletiva e que cumpria um papel importante nas mentes e, mais uma vez, deslegitima a sua caracterização como saber menor.

Assim, a história cumpre, nas sociedades islâmicas medievais, uma posição que, mesmo oficialmente não constando nos saberes mais valorizados, através da classificação de ciências adotadas pelos sábios, se destaca na sua função social e política. Nascida primeiramente da Sunna, isto é, do recolhimento dos gestos do Profeta, a história se abre para o desafio de contemplar todo o percurso dos árabes no mundo, de sua criação aos dias atuais, contemplando o imenso território ocupado pelo 'Islām, cumprindo a função de criar uma memória coletiva unificada, isto é, da' Umma ${ }^{33}$ mesmo garantindo uma ideia de heranças nacionais específicas de cada região que o 'Islām ocupava -, e de espalhar pelas diversas nações os ideais e aspirações do 'Islām, a historiografia garantiu um espaço importantíssimo, não institucional, mas sim, subjetivo: de identidade dentro da cultura árabe. Veremos que o Kāmil, de Ibn al-Athīr, foi composto para cumprir tal função na sociedade árabe do século XIII.

\section{IBN AL-ATHĪR, O AUTOR.}

Ibn al-Athīr nasceu na cidade de Jazirat Ibn 'Umar' ${ }^{34}$, em 1160. É o segundo dos três filhos de 'Abū al-Karam Muhammed 'Athīr al-Dīn, que atuava na administração desta província pertencente ao principado de Zinkī desde 1128, quando este sobe ao poder em Mossul. Ibn al-Athīr passou sua infância nesta província até a mudança de sua família para Mossul $^{35}$. Mesmo sem uma definição exata deste acontecimento, a mudança da família é um marco para a carreira do nosso historiador. Mossul é, neste momento, um importante centro de conhecimento. A dinastia dos Atābegs ${ }^{36}$ encorajava e patrocinava ações de educação e bem estar público, o que atraía muitos letrados para a cidade. É neste ambiente que Ibn al-Athīr cresce, em meio aos maiores sábios da poesia, do direito, das tradições. Devido ao grande prestígio que seu pai gozava por seu cargo em Mossul, Ibn al-

\footnotetext{
${ }^{33}$ Comunidade muçulmana.
}

${ }^{34}$ Atual Cizre, pertence à Turquia. Localizada próxima às fronteiras atuais da Síria e do Iraque, à cerca de 140 quilometros de Mossul.

${ }^{35}$ No apêndice do primeiro tomo oriental do Recueil des Historiens de Croisade, D, Slane (1872-1906, p.752) atribui esse deslocamento a uma possível queda na posição de Athīr al-Din ocasionada após a morte de seu suserano Quṭb al-Dīn Muhammad e a subida de Sinjar Šāh ao governo da província. Na introdução à tradução do Kāmil, D. S. Richards (2010, p. 1) aponta o ano de 1183 para a mudança de Athīr al-Din e sua família, mas essa informação também é contestada por Mahmood ul-Hasan (2005, p. 45), que acredita que a data da saída da família aconteceu em 1169, quando o pai do cronista foi nomeado o tesoureiro de Quṭb al-Dīn Muḥammad, indo para Mossul para o exercício da função.

${ }^{36} \mathrm{O}$ atābak, ațābak ou 'atābik (atābeg), é um título de origem turca composto de duas palavras: ata, "pai", e beg, que é um título de nobreza. 0 termo atābeg aparece pela primeira vez na história muçulmana durante o período Seljúquida (séculos XI, XII), quando foi usado como um título honorífico dado a guarda-tutores de jovens príncipes turcos. Depois, passou a representar o sultão com reconhecimento nominal da autoridade califal. LEVANONI, Amalia. "Atābak (atābeg)", in: Encyclopaedia of Islam, THREE, Edited by: Kate Fleet, Gudrun Kramer, Denis Matringe, John Nawas, Everett Rowson. Consulted online on 23 September 2016 http://dx.doi.org/10.1163/1573-3912 ei3 COM 23689 First published online: 2010 


\section{capítulo de dissertação}

Athīr pôde circular livremente entre a elite e ter acesso ao mais alto nível de aprendizado, afinal, tinha autorização para participar das aulas ministradas por vários estudiosos.

Em Mossul, a família continuou a servir a dinastia zânguida na carreira administrativa ${ }^{37}$. Apesar de não ter seguido a mesmo caminho, 'Abū Hasan 'Ali 'Izz al-Dīn, nosso Ibn al-Athīr, por diversas vezes atuou como enviado de Mossul à Bagdá, Alepo, Damasco e outras cidades, aproveitando as suas missões diplomáticas para entrar em contato com outros estudiosos e completar a sua formação. Apesar dessa proximidade com a dinastia zânguida, D.S Richards (2010, p.1) afirma que não é possível atestar que ele era um servidor pago pela dinastia, pois os relatos usam a expressão "associado", o que não deixa claro se ele era um funcionário pago ou um amigo pessoal da casa do vizir. 0 que é certo é que ele manteve-se sempre próximo e foi reconhecido pela dinastia como grande sábio. D. Slane faz referência ao relato do dicionário biográfico de Ibn Hallikān, em que ele conta sobre o encontro que teve com Ibn al-Athīr no ano de 1229 e fornece sua impressão sobre o historiador, dizendo que "era um mestre de primeiro escalão por seu conhecimento relativo às tradições relacionada ao Profeta, à história antiga e moderna, à genealogia dos árabes, às aventuras dos antigos árabes e de suas jornadas célebres" e ao seu comportamento pessoal, que demonstrava "um homem de grande mérito, possuidor das mais nobres qualidades e cheio de condescendência" (Ibn Hallikān, apud . Recueil [...], 1872-1906, p. 753).

Ibn al-Athīr dedicou a maior parte de sua vida à composição de suas obras históricas e biográficas ao mesmo tempo em que atuava como professor nas madrassas. Seu reconhecimento como intelectual fez com que sua casa fosse um ponto de encontro de muitos sábios que iam até Mossul para ouvir e aprender com ele.

Das obras produzidas por Ibn al-Athīr, somente duas chegaram até nós: "Uma História dos Atābegs de Mossul"38, composta entre 1211 e 1218 e o Kitāb al-Kāmil fi l-ta'rīkh, ou "O Livro Perfeito de História". Atesta-se que ele também escreveu um resumo dos Ansāb de al-Sam‘ānī e uma história dos companheiros do Profeta Muhammad ${ }^{39}$. D. Slane (Recueil [...]1872-1906, p. 754) ainda atribui ao historiador um tratado de retórica, um compêndio de notas e observações e um texto sobre a Guerra Santa ${ }^{40}$.

\footnotetext{
${ }^{37} \mathrm{O}$ irmão mais velho, Abu l-Sa'adat al-Mubarak, foi conselheiro do príncipe de Mossul, Arslan Chah, enquanto seu irmão mais novo, Abu l-Fath Nasr Allāh, serviu nas chancelarias de Saladino em Damasco e depois retorna a Mossul, à serviço ed Nacer ed-Din.

${ }^{38}$ Al-Ta'rikh al-bahir fi l'dawla al-atabakiyya, dedicada ao filho de Nur al-Din Arslan Šāh, Izz al-Din Mas'ud. Publicado e traduzido no Recueil des Historiens des Croisades. T.II 1, Paris, 1872. E uma nova edição de Abd al- Qadir Ahmad Tulaymat, Cairo, 1963.

${ }^{39}$ Usd al-ḡāba fì ma rifat al-șaḥāba.

${ }^{40} \mathrm{O}$ tratado de retórica se intitularia, segundo D. Slane, Al Djema el-Kebir, (o grande coletor), entretanto este nome está incorreto, pois sua tradução seria, na realidade, 'A Grande Mesquita' (al-Jāmi' al-Kabīr). Não conseguimos encontrar outra citação à obra para corrigir o nome do tratado; 0 compêndio Tuhfat $a l-\dot{G} a r a \bar{i} i b$, (presente de maravilhas e dons de raridade) e uma obra sobre guerra santa, Kitā $b$ al-jihād (Livro do jihād). Essas informações constam somente nessas notícias publicadas por D.Slane (Recueil [...]
} 


\section{capítulo de dissertação}

Certamente, a obra mais célebre do autor é o seu Kāmil fi l'Ta'rikh, considerado um dos maiores trabalhos de história geral para o período da Idade Média no mundo islâmico. Ela é utilizada como uma fonte original e contemporânea para quem estuda o período das Cruzadas. Não somente por seu conteúdo, mas por sua metodologia de análise das fontes e de organização do texto, Ibn al-Athīr é citado por Francesco Gabrieli (2001, p. 386), como "o único verdadeiro historiador desse período".

\section{KITĀB AL-KĀMIL FI L-TA'RĪKH: TRADUÇÕES}

Para este estudo, duas publicações diferentes da obra al-Kāmil fi'l - ta'rikh serão utilizadas, a primeira presente no Recueil des Historiens des Croisades, Historiens Orientaux $^{41}$, com tradução do árabe para o francês. Essa coletânea, antes amplamente utilizada pelos pesquisadores, foi, recentemente, alvo de críticas de estudiosos da historiografia árabe. Eles argumentam que há problemas na escolha de textos que a integram , discordam da interpretação dos $\operatorname{copistas}^{42}$, e alegam que as reedições não apresentam nem correção de erros prévios, nem atualização que levasse em conta a descoberta de outras fontes árabes importantes do período, por exemplo, a Crônica de Damasco de Ibn alQalānisī, desconhecida à época da publicação da primeira edição do Recueil des Historiens des Croisades. Entre os críticos da obra, está Claude Cahen (1970, p. 104), que afirma que a sua utilização como fonte exclusiva nos estudos orientalistas é perigosa.

A segunda, publicada na Coleção Crusade Texts in Translation, com tradução de D.S Richards, do árabe para o inglês ${ }^{43}$. D.S Richards usou a edição de Dar Șādir como base para elaborar sua tradução, contudo, diferentemente do Recueil des Historiens des Croisades, sua edição apresenta apenas o texto traduzido, sem acrescentar-lhe a versão na língua original. Mesmo assim, o trabalho de Richards tem o mérito de oferecer uma tradução completa do texto de Ibn al-Athīr relativo ao período que compreende da Dinastia

1872 -1906, p. 755) e são apresentadas sem qualquer referência. Como outras fontes mais recentes não citam essas duas últimas obras, entendi que elas deveriam ser colocadas como uma atribuição incerta.

${ }^{41}$ IBN AL ATHĪR. Al-Kamil fi al-Tarikh in Recueil des Historiens des Croisades. Historiens Orientaux. V. I. Paris, 1872 - 1906. Publicada sob a responsabilidade da Académie des Inscriptions et Belles - Lettres, a partir da segunda metade do século XIX, a coleção Historiens Orientaux faz parte do grande Recueil des Historiens des Croisades. Essa coleção é composta por cinco volumes de cópias de fragmentos originais e suas respectivas traduções, pertencentes a diversos historiadores. 0 primeiro volume, em que se encontra a primeira parte dos fragmentos do Kãmil, foi publicado pela primeira vez em 1872, por D. Slane. Para o recolhimento dos fragmentos referentes ao Kāmil, MM. Reinaud e Défemery utilizaram os seguintes manuscritos: os suplementos árabes no 740, volumes desaparelhados, pertencentes a exemplares diferentes, e 741 da Biblioteca Nacional da França; o manuscrito da UPPSALA - um volume de fragmentos copiados em Constantinopla pela biblioteca do Instituto (R.H.C. V. I, p.765).

42 GABRIELI, Francesco. Chroniques arabes des Croisades. Tradução Viviana Pâques. Sindbad/Actes Sud, 2001 p. 20.

${ }^{43}$ IBN AL ATHĪR. IZZ AL DIN. The Chronicle of Ibn al Athir for the Crusading Period from al Kamil I l-ta-rikh. Part 2: The Years 541-589/1146/1193: the Age of Nur al Din and Saladin. Crusade Texts Translations, 15. Trad. D.S. Richards. Ashgate. Surrey, 2010. 


\section{capítulo de dissertação}

Zânguida ao governo de Saladino. Destarte, ao contrário do Recueil des Historiens des Croisades, não encontramos uma mera seleção de extratos, o que nos permite apreciação mais acurada de como as Cruzadas eram contempladas em uma obra historiográfica que visava analisar o mundo islâmico em geral. Além destas duas traduções, o texto foi publicado integralmente em língua árabe ${ }^{44}$ em diversas oportunidades

\section{KITĀB AL-KĀMIL FI L-TA'RĪKH: ORIGENS, COMPOSIÇÃO E CRÍTICAS.}

Não se sabe ao certo a data em que Ibn al-Athir começou a compor o Kâmil. Entretanto, o próprio autor descreve, na introdução, o percurso de sua composição: ele declara que escreveu a crônica universal dando, primeiramente, um título diferente, alMustaqșā fĩ al- ta'rīhn, até que o vizir Badr al-Dīn Lu'lu', a quem Ibn al-Athīr anuncia dedicar a obra, ordena a sua publicação. Acredita-se que ele ainda a corrigiu e a completou entre 1218/1219 e 1230/1231 (Micheau, 2007. p. 83) ${ }^{45}$.

Ora, o Kāmil foi elaborado num período em que o Império Islâmico viveu uma de suas maiores crises e esse ambiente certamente contribuiu na visão histórica e na obra de Ibn al-Athīr. O Próximo Oriente, desde o século X, foi palco de transformações marcadas pela fragmentação do poder e a consequente afirmação de dinastias dirigidas por classes militares não árabes, às quais a realidade do poder militar é confiada. Após a morte de Mālik Šāh, sultão do Império Seljúcida, o reino que compreendia uma parte da Ásia Central, Ocidental e Egito, se ramificou em diversos principados, que passaram a disputar o controle das regiões. A situação da região se agravaria com a chegada da Primeira Cruzada, que à primeira vista dos muçulmanos, não passava de um resquício das guerras bizantinas. Imersos em seus próprios conflitos internos, nenhuma grande força foi mobilizada por esses governantes e a ocupação de territórios da Síria e da Palestina, em 1098 e 1099, ocorreu sem grandes reações muçulmanas. O cronista Ibn al-Qalānisī relata esta falta de consciência do sentido das Cruzadas no ano de 1119:

\footnotetext{
Neste ano, chegaram do território franco, informações e rumores segundo os quais os Francos visavam certas cidades e fortalezas, concordando em espalhar danos e caos nesses locais, aproveitando que o 'Islām negligenciava realizar qualquer expedição ou o jihād contra eles. Então, se colocaram a realizar os preparativos neste sentido. (Ibn al-Qalānisī, 1983, p.318)
}

\footnotetext{
${ }^{44}$ D. S Richards (2010, p.6) apresenta as outras traduções do Kamil: um texto integral da crônica foi editado por C.J. Thornberg e publicado pela Leiden em 14 volumes, entre os anos de 1851 e 1876 . Em 1884 e 1886, duas edições foram publicadas no Cairo. Uma nova edição baseada na publicação de Thornberg foi realizada por Dar Sadir e publicada em Beirute, em 1965-7. Nos últimos anos duas novas edições foram publicadas em Beirute: uma em 1997, pela Dār al-Kitā b al-'Arabī, preparada por 'Umar Tadmurī; a outra, em 1998, editada por Abū-Fidā, publicada pela Dār al-Kutub, al-'Ilmiyya.

${ }^{45}$ A autora cita, nesta passagem, o estudo de D.S. Richards, Ibn al-Athīr and the later Parts of the Kāmil: A Study of Aims and Methods, in. D.O Morgan (ed.), Medieval Historical Writings in the Christian and Islamic World, London, 1982. p. 76-108, que não tive acesso.
} 


\section{capítulo de dissertação}

Esses principados muçulmanos constituíram-se apoiados, sobretudo, em sua força militar, composta, principalmente, por soldados turcos. Esses militares passaram a se destacar inclusive por suas habilidades políticas e acabaram substituindo seus mestres seljúcidas, dando origem às dinastias dos Atābegs. Neste momento, o Califa Abássida não representava mais que a autoridade religiosa, enquanto o poder era exercido, de fato, pelos sultões, que governavam o fragmentado território islâmico. As pressões internas provocadas pela expansão dos territórios do atābeg Zangui e a grande ameaça externa vinda dos cruzados dominou a primeira metade do século XII. A região conheceria uma relativa estabilidade política com Nūr ad-Dīn, filho e sucessor de Zangui, que conseguiu reunir sob sua autoridade toda a Síria muçulmana e transformar o jihād contra os francos numa espécie de política de estado. 0 mesmo ocorreu com Saladino, que manteve as mesmas políticas de seu antecessor e garantiu uma das maiores vitórias islâmicas no final do século XII, ao reconquistar a cidade de Jerusalém. Todavia, à morte de Saladino, em 1193, seguiu-se uma guerra civil entre os seus descendentes, que almejavam sucedê-lo. Uma nova fragmentação política e um enfraquecimento dos reinos teve lugar, deixando estes reinos sem nenhuma força para combater o novo inimigo que se aproximava, os Mongóis, que infringiram a primeira tentativa de ocupação das terras islâmicas no mesmo momento em que os francos invadiam o Egito, de 1218 a 1221. 0 tom adotado por Ibn al-Athīr para descrever a ameaça que os conquistadores mongóis representavam para o mundo islâmico evidencia o temor que rondava a população muçulmana destes territórios:

\footnotetext{
Os acontecimentos que vou narrar são tão horrorosos que por muitos anos evitei fazer qualquer alusão a eles. Não é fácil anunciar que a morte se abateu sobre o 'Islām e os muçulmanos. Ah! Como eu teria gostado que minha mãe não me tivesse posto neste mundo, ou então que eu tivesse morrido sem ter sido testemunha de todas essas desgraças. Se alguém lhes disser que a Terra nunca conheceu semelhante calamidade desde que Deus criou o homem, não hesitem em acreditar, pois esta é a pura verdade. Entre os dramas mais célebres da História, cita-se geralmente o massacre dos filhos de Israel por Nabucodonosor e a destruição de Jerusalém. Mas isso não é nada em comparação com o que acaba de acontecer. Não, até o final dos tempos, jamais será vista uma catástrofe de tamanha amplitude. (Ibn al-Athīr, apud Amin Maalouf, 2007, p.219)
}

Além das querelas internas, o 'Islām estava, também, sob anúncio de diversas ameaças externas. 0 temor que assombrava a população muçulmana não era mais a instabilidade política nascida das quedas e trocas de dinastias. Agora, existia uma ameaça sobre o próprio 'Islām e a continuidade de sua existência:

O'Islām, todos os seus habitantes e todos os seus territórios estavam sob o ponto de ser submergidos. Os tártaros avançaram do Oriente até as regiões do Iraque, do Adharbayjan, de Arran ${ }^{46}$, etc, como exporemos, se Deus quiser. Os Francos avançaram desde o Ocidente e tomaram uma [cidade] tal como Damieta, no Egito, falta de fortificações para a proteger dos inimigos. Todo o país, no Egito e na Síria, esteve sob o ponto de ser conquistado e todas as pessoas temeram

\footnotetext{
${ }^{46}$ Províncias localizadas no atual Iran e Azerbaijão.
} 
face [aos Francos], esperando noite e dia pelo desastre. (Ibn al-Athīr, apud Micheau, 2007, p. 86) ${ }^{47}$

As disputas internas, a desunião e o temor da aniquilação estimularam um envolvimento geral entre as elites para reacender uma força contra ameaças internas e externas, e as classes letradas tentavam criar alguma esperança a partir de seus escritos. Logo, temas sobre o bem, o interesse e o destino comuns passaram a ser recorrente na historiografia. Ibn al-Athīr, então, desenvolveu seu senso de história baseado em um conceito universal do 'Islām como uma força espiritual que uniria os povos das diferentes etnias e regiões; como uma mensagem de igualdade, justiça e irmandade. Essa prática historiográfica é afirmada pelo próprio Ibn al-Athīr:

Os orientais negligenciavam os relatos sobre o Ocidente e os ocidentais negligenciam o que concerne o Oriente...Vendo isso, eu me coloquei a compor uma história reunindo os recitos relativos aos soberanos de Oriente e Ocidente... Eu não pretendo reunir todos os eventos de natureza histórica, pois pode ter escapado àquele que se encontra em Mossul, o que se passava no extremo Leste ou no extemo Oeste. (Ibn al-Athīr, apud Micheau, 2007, p. 84)

Sua história universal, sua Historia Perfeita, foi escrita contemplando todo o percurso da comunidade islâmica: o período dos Patriarcas, dos profetas, e dos primeiros soberanos; depois, a história da Pérsia, Grécia, dos Romanos até a história do período pré-islamico e dos dias de batalha. A isso, segue-se a história dos quatro primeiros califas, do califado Omíada e Abássida, além da descrição em detalhes outras dinastias como a dos Seljúcidas, Atābegs e Aiúbidas (Mahmood Ul-Hasan. 2005, p.59-60).

O orientalista Hamilton Gibb sugere que este universalismo tem suas raízes no sentimento religioso, que, na historiografia encontrou um novo ambiente para se desenvolver. Essa consciência guiou o pensamento histórico de Ibn al-Athīr, que concebeu sua história islâmica como única e uniforme, escrevendo desde o início, isto é, da criação do Mundo, até o seu tempo, dando a mesma importância a todas as fases e lugares onde o 'Islām, não importasse a dinastia, esteve presente. Para Gibb, o equilibrio e a abrangência do trabalho realizado por Ibn al-Athīr deve-se à sua forte e profunda consciência desse fenômeno (Gibb, apud Ul-Hasan, 2005, p. 175).

Para composição da primeira parte de sua obra, Ibn al-Athīr utilizou, como principal fonte, a texto de 'Abū Ja'far Muhammad Ibn Jarīr al-Ṭabarī, Ta’rīh al-Tabarī. Mediante essa informação, muitos orientalistas tendem a realizar, ao meu ver, um julgamento equivocado sobre o Kāmil, como é o caso de Carra de Vaux (1921, p.121), que considera que Ibn al-Athīr se limitou a continuar o trabalho al-Ṭabarī. Para ele, o Kāmil nada mais seria que um resumo da obra de al-Ṭabarī, com a diferença de acrescentar fatos retirados de outras fontes e contemplar um intervalo temporal maior com uma duração maior. Ademais, Carra de Vaux afirma que a função real do Kāmil era a de reavivar, mesmo que

\footnotetext{
${ }^{47}$ Colchetes do autor.
} 


\section{capítulo de dissertação}

parcialmente, o trabalho de al-Ṭabarī a fim de colocá-lo ao alcance do público, uma vez que o Ta'rīh al-Ṭabarī, graças à sua extensão e complexidade textual, tinha circulação restrita. Portanto, para Vaux, o Kāmil tinha importância apenas por guardar, em si, uma relação com o trabalho de al-Ṭabarī. Ainda nesta perspectiva de referência à al-Ṭabarī, Francesco Gabrieli (Gabrieli: Khan, 1979, p. 90) relata que os orientalistas ocidentais passaram, com relação ao Kãmil, de uma supervalorização excessiva a uma desvalorização radical, porque, segundo ele, a obra de Ibn al-Athīr foi conhecida pelo ocidente antes do Ta’rīh al-Tabarī. Quando a obra do jurista e teólogo persa foi publicada no ocidente, o Kāmil passou a ser desprezado, já que os pesquisadores tinham, a partir de então, acesso à fonte original para a história dos primeiros séculos do 'Islām. Mesmo o período contemporâneo à Ibn al-Athīr, em que sua escrita era vista como fonte primária, passaria a receber críticas após a descoberta da Crônica de Damasco, de Ibn al-Qalānisī (CAHEN, 1970, p. 99), além das obras de 'Imād al-Dīn, al-Isfahānī, entre outros, contemporâneos ao autor. Para Gibb (1935, p. 745-746), não há mais legitimidade em todo o trabalho de Ibn al-Athīr na medida em que todas as fontes utilizadas pelo historiador são conhecidas e acessíveis. Desde então, a obra é alvo de críticas pelos orientalistas ocidentais.

Entretanto, Mahmood ul-Hasan ${ }^{48}$ realiza uma grande análise das fontes utilizadas por Ibn al-Athīr e mostra que, além do Ta'rīh̆ al-Ṭabarī, o autor lança mão de muitas outras fontes, que complementam as de al-Tabarī, as quais, por sua vez, não foram meramente acrescentadas, uma vez que Ibn al-Athīr não se limita a adicioná-las ao seu texto, ele, na verdade, também realiza um verdadeiro trabalho de crítica das informações originais $^{49}$. De fato, ul-Hansan mostra que Ibn al-Athīr utiliza fontes não trabalhadas por al-Țabarī, afirmando que o Kāmil apresenta momentos da história muçulmana totalmente desprezadas pelo historiador persa que o precedeu. A pesquisa de ul-Hasan aponta com clareza que, em alguns casos, há passagens semelhantes entre textos de Ibn al-Athīr e outras fontes que não al-Țabarī; noutros, que relatos presentes no Kāmil estão ausentes na obra do historiador persa; por fim, que há momentos em que a proximidade entre os dois historiadores só pode ser constatada se a pesquisa for especulativa, uma vez que é impossível, com as fontes de que dispomos, saber com certeza quais são as obras que Ibn al-Athīr leu para compor o Kāmil. De qualquer modo, o minucioso trabalho de ul-Hasan permite afirmar que al-Ṭabarī não é a única fonte de Ibn al-Athīr.

\footnotetext{
${ }^{48}$ UL-HASAN. Op.cit. passim. Esta obra é uma das poucas referência bibliográfica acessíveis que faz uma análise específica de toda obra Kāmil, de Ibn al-Athīr, em uma língua diferente do árabe. Como não tive acesso à obra completa de Ibn al-Athīr, por estar publicada somente em língua árabe, tive que estabelecer um diálogo comparativo entre as críticas feitas ao Kāmil e a análise de ul-Hasan - sem, contudo, deixar de criticá-la, igualmente a fim de tentar responder às questões impostas pela crítica ocidental ao trabalho de Ibn al-Athīr.

${ }^{49}$ Como pode ser visto na página 158 da tradução de D.S. Richards, quando ele critica a sua fonte.
} 


\section{capítulo de dissertação}

Assim, ainda que a base para o período que trata a criação do mundo até os primeiros séculos da Dinastia Abássida tenha como fonte a história de al-Ṭabarī, é possível discernir, como demonstra ul-Hasan (2005, p. 71-72), todas as outras fontes utilizadas: Na primeira parte do Kāmil, por exemplo, o autor utiliza a Sīra de Ibn Ișhāq, e o Kitāb al-Ma'ārif, de Dīnāwarī, para tratar das informações relativas aos profetas judeus e cristãos. 0 autor ainda levanta a hipótese de Ibn al-Athīr ter retirado informações da Torá numa tradução para o árabe. No que concerne à parte pré-islâmica de sua obra, Ibn al-Athīr apresenta um senso de proporção quanto às fontes, isto é, ele utiliza todas as fontes possíveis que estavam à sua disposição a fim de construir uma argumentação que considerasse honesta e equilibrada. Nesta mesma sessão, Ibn al-Athīr atenta para o fato de al-Ṭabarī não dar nenhuma notícia dos 'Ayyâm, dos quais ele próprio trata de forma clara e rica. 0 problema que ul-Hasan (2005, p. 76) nota é que "Ibn al-Athīr encontrou uma vasta literatura nos 'Ayyâm al-'Arab. Mas, como ele não menciona as autoridades, é muito difícil traçar todas as fontes, apenas algumas". A partir disso, a historiografia contemporânea critica o fato de o Kāmil não citar as autoridades em que se apoia, o que ocorre ao longo de toda obra.

Quanto à porção dedicada à história pré-islâmica da Pérsia, Ibn al-Athīr segue a mesma ordem estabelecida por al-Ṭabarī, entretanto, adota uma postura crítica quanto a história persa - crítica da qual o al-Ṭabarī se isenta:

\footnotetext{
De fato, existem superstições Persas junto com outras coisas já mencionadas e eu as narrei de modo que a ignorância persa seja conhecida, porque eles, geralmente, fazem comentários caluniosos contra os árabes com respeito à ignorância destes (Ibn al-Athīr, apud Ul-Hasan, 2005, p. 80).
}

Ora, este comentário de Ibn al-Athīr deixa claro uma rivalidade existente entre uma memória árabe que se pretende universal e um esforço de memória regional que a historiografia persa praticava e que rememorava o período anteislâmico. Essa visão crítica ao relato de al-Ṭabarī é igualmente marcante na sessão que trata da dinastia Omíada, cuja versão dos fatos não é, segundo Ibn al-Athīr, autêntica. 0 historiador, então, utiliza outras fontes como Ma'sūdī e al-Balādurī, para fornecer um relato que julga mais coerente. (Ul-Hasan, 2005, p. 107)

Mahmood ul-Hasan (2005, p. 83) observa que a utilização de outras fontes está clara na obra de Ibn al-Athīr. Existem passagens do Kāmil que, se comparadas ao Ta'rīh al-Ṭabarī, apresentam tanto maior extensão como mais informação. Ele cita o exemplo do relato em que o autor narra o encontro entre o rei da China e Alexandre, bem como os eventos subsequentes que os levaram ao enfrentamento. 0 mesmo ocorre com o relato da queda da Dinastia Omíada, que assim como no exemplo anterior, inexistem no Ta'rīh al-Tabarī. Além disso, Ibn al-Athīr utiliza documentos ocidentais em grande escala, como do espanhol a l-Rāzì e de 'Abd al-'Azīz Ibn Šaddād, emigrado para Damasco. Até onde se sabe, ele é o primeiro historiador do Oriente muçulmano a lançar mão de documentos ocidentais (Cahen,1986, p. 185). 


\title{
capítulo de dissertação
}

Outra característica a se destacar em Ibn al-Athīr, é uma tendência a ignorar a contenda entre historiadores pró Omíadas e Abássidas, descrevendo, em sua história, momentos e locais que foram desprezados por al-Tabarī, que, como se sabe, possuía uma tendência pró Abássida. Na obra de al-Ṭabarī, não se menciona nada sobre a região da Espanha, enquanto Ibn al-Athīr oferece informações detalhadas sobre o território Omíada. Além disso, nosso historiador expressa certo desprezo pelas preocupações de alguns historiadores que se ocupam de pequenas querelas entre sunitas, xiitas, e outras minorias presentes na sociedade islâmica. Ibn al-Athīr diz:

\begin{abstract}
Muitos (historiadores) enegrecem o pape ${ }^{50}$ com coisas sem importância, que seria melhor se desconsideradas e não perpetuadas nos escritos. Isso se aplica a coisas tais como "tal e tal" - um judeu ou um cristão - foi dada uma veste'. 'O custo cotidiano aumentou'. 'Fulano - falando de algum criminoso - foi honrado e cicrano - falando de algum líder muçulmano de caráter exemplar foi humilhado. (Mencionar) essas (más praticas) podem causar a sua aplicação a outros casos[...] (Ibn al-Athīr, apud Rosenthal, 1968, p. 336-337)
\end{abstract}

Finalmente, para a primeira parte do período Abássida, além das narrativas do Ta'rīh al-Tabarī, Ibn al-Athīr conta com os livros que retratam as histórias mais locais, como As Crônicas de Damasco, de Ibn al-Qalānisī, o Tajārib, de Miskawayh ou mesmo livros de poesia, como de Muhammad Ibn Hānī, poeta que possuía vínculos com a Dinastia Fatímida. (UL-HASAN, 2005, p. 135 et seq). Ibn al-Athīr declara que, para a segunda parte, baseou-se sobretudo em testemunhos orais recolhidos em viagens - conversas com mercadores, soldados, etc -, além de consultar documentos oficiais e tratados secretos como: "Eu vi a carta escrita por Saladino para seu irmão Šams al-Dīnn1, que estava em Damasco, mencionando o incidente e começando com um verso. Ele recorda em sua carta que a morte pairou sobre nós muita vez, mas Deus nos salvou" (Ibn al-Athīr, apud Ul-Hasan, 2005, p. 153). Ora, essas correpondências integravam documentos oficiais, provalmente oriundos de arquivos de chancelaria. Foi devido ao prestigio de que gozava nas elites e graças às amizade cultivadas nos altos postos do governo que Ibn al-Athīr teve acesso a esse tipo de documentação, seja à possibilidade de ser ter acesso a testemunhas oculares de vários eventos importantes de sua época. Por isso, consideram-se originais os relatos que se referem ao período entre o século XII e o primeiro quarto do século XIII.

Pode se considerar que uma das maiores novidades apresentadas por Ibn alAthīr é a maneira como a narrativa se constrói no Kāmil, ainda que a obra siga, de certo modo, a forma do relato analítico, que, por sua vez, era usado na história islâmica tradicional. É no centro dos esquemas, pelos quais a História árabe efetua seu discurso, que encontramos o objeto da escrita histórica, organizado pelo relato, de modo serial sob a forma de uma sequência. E é a estrutura da sequência que nos serve de guia nas concepções imanentes do conhecimento histórico na cultura árabe islâmica. Até agora,

\footnotetext{
${ }^{50}$ No sentido de deitar a tinta sobre o papel.

${ }^{51}$ Mais conhecido como Tūrān Šāh.
} 


\section{capítulo de dissertação}

essa estrutura ano a ano era a mais utilizada. Assim, para adequar-se ao método, os autores tinham a tendência de fragmentar os eventos em episódios classificados em divisões por ano ou sobre classificação de fontes, de forma que a integralidade dos eventos se perdia junto com os antecedentes essenciais e seus diferentes aspectos e fases. Eles ficavam dispersos pelo texto, pois a exigência rígida desse método obrigava que os diversos acontecimentos e momentos do mesmo evento estivessem presentes em seu lugar temporal, afastados de seu contexto.

Ibn al-Athīr não respeita a rigidez metodológica, ao contrário, está preocupado em fornecer uma explicação para os eventos e não apenas em realizar um mero relato. Para isso, ele é obrigado a sair do plano rigoroso da forma analítica de exposição. 0 Historiador Aziz al-Azmeh (1986, p. 416), ao analisar a forma de expressão das narrativas árabes nas obras históricas, apresenta a postura diferenciada de Ibn al-Athīr na composição do Kāmil. Ele explica que os diversos aspectos do evento, em termos de temporalidade, isto é, o começo, meio e fim, são reduzidos a um momento intemporal destacado de seu contexto, nas estruturas analíticas de exposição. Logo, recolocá-los em seu lugar demanda um trabalho que ultrapassa a narrativa em questão e necessita a produção de outra narrativa, mais coerente. É possível perceber esta atitude de desrespeito à cronologia quando Ibn al-Athīr narra a vitória de Ṭugril III sobre as tropas de al-Nāșir em 1188, mas narradas em 1189, justificada assim: "Seria conveniente apresentar este episódio antes, mas eu o retardei a fim de que os eventos relatados antes seguissem uns aos outros e que cada evento fosse ligado a um outro" (Ibn al-Athīr, apud Micheau, 2005, p. 88). Neste caso, ele não queria interromper a narrativa sobre as campanhas de Saladino, que ocorreram no ano relatado.

Al-Azmeh (1986, p. 417) atenta para o fato de que a crítica de Ibn al-Athīr não é a separação em si das diferentes unidades do relato histórico, ele explica que é possível dividir os eventos em unidades menores, cada uma compondo um evento comportando um aspecto inicial, imperfectivo e final, ou seja, constituindo-se independente e apresentando a possibilidade de se observar as ações que ele relata e que comportam o evento a partir da abstração dos eventos que o antecedem e o sucedem. Assim, não seria a duração de um evento no tempo o aspecto determinante para considerá-lo um evento como tal, mas a sua unidade de interpretação no seu sentido e no contexto do relato. Portanto, Ibn al-Athīr critica a interrupção da coerência interna entre as fases destas unidades narrativas, o que ocorre em autores como al-Ṭabarī, que põe fim em relatos para apresentar informações secundárias.

Assim, dado que o evento implica um movimento unilateral entre dois instantes que representam os limites temporais de uma ação, ele pode ter o tamanho que sua integralidade exige, ultrapassando, por vezes a organização analítica. Em uma passagem da introdução do Kāmil, Ibn al-Athīr deixa claro que sua metodologia de trabalho rompe com o método tradicionalista: 
al-Ṭabarī mencionou um enorme inventário para a maior parte dos eventos, cada um, semelhante ao precedente ou mais sucinto, por vezes, acrescentando ou emitindo pequenas coisas. Eu me propus a completar os inventários, transcrevendo-os e acrescentando o que não contemplavam antes, colocando cada coisa em seu lugar. Assim tudo [o que concerne ao] evento, apesar da diversidade de vozes, se transformou numa narração única (Ibn alAthīr, apud Micheau, 2005, p. 90 - 91).

Essa mudança na estrutura narrativa visa produzir um relato unívoco, mostrando as causas e os efeitos dos eventos, ou seja, sem se limitar em realizar uma compilação de diversas fontes acomodadas dentro de uma sequência de datas. Em outras palavras, diferentemente do Ta'rīh al-Tabarī, Ibn al-Athīr propõe dar um tratamento crítico às suas fontes. Esse modelo, que pretende reunir ao relato a imensidade de sua informação, será, mais tarde, retomado por Ibn Hुaldūn (Martinez-Gros; Micheau; Touati, 2007, p. 7). Certamente, este trabalho não escapa a um julgamento pessoal do autor na escolha das fontes - o que não o difere de nenhum outro historiador - o que o leva a acrescentar informações inexistentes nas fontes utilizadas, sem citar, muita vez, de qual fonte retirou cada informação. Esses, talvez, sejam os maiores motivos que tenham levado historiadores contemporâneos, como Gibb e Gabrieli, à crítica enfática do trabalho de Ibn al-Athīr.

Gabrieli (1970, p. 227) acusa o autor de usar suas fontes com muita liberdade e de forma tendenciosa, apesar de celebrar a originalidade de sua narrativa pelos mesmos motivos. Gibb (1935, p. 746), por sua vez, faz uma extensa crítica à obra de Ibn al-Athīr, acusando-o de ser relapso quanto aos detalhes de fatos, cronologia, interpretação das fontes e "de não estar inteiramente livre das tendências românticas e empíricas que eram visíveis sobre uma ampla gama da literatura islâmica medieval". Além disso, ele também critica a composição da narrativa de Ibn al-Athīr, acusando-o de suprimir elementos das narrativas originais e alterar o teor ou frase de suas fontes ${ }^{52}$. Também acusa o historiador de fazer o que chama de "truques de compilação" (Gibb, 1935, p. 747-749), isto é, agrupar itens que, segundo Gibb, não tem nenhuma conexão, e reunir eventos distintos num mesmo relato, portanto, na mesma data.

Ora, a liberdade com a qual Ibn al-Athīr trata as suas fontes na composição da sua obra deve ser entendida dentro da perspectiva com que o autor pensou sua narrativa. Para Ibn al-Athīr, essa operação partia da lógica de que ao não recopiar textualmente suas fontes, mas trabalhar criticando-as, resumindo-as, recompondo-as e interpretando$\mathrm{as}^{53}$, não faria sentido dar os asānīd dos textos, já que eles não estão recopiados em sua integralidade.

A historiografia contemporânea também é crítica a uma abordagem tendenciosa

\footnotetext{
52 Ibdem, p. 747.

${ }^{53}$ Supra, p.23.
} 


\section{capítulo de dissertação}

de Ibn al-Athīr, que, por estar ligado à casa dos atābegs zânguidas, submetia as ações de Saladino a uma avaliação severa e parcial quanto às ações do sucessor de Nūr ad-Dīn. De fato, a obra dedicada aos atābegs de Mossul ${ }^{54}$ realiza um elogio da dinastia zânguida com sucesso. Entretanto, no Kāmil, o que Ibn al-Athīr faz é realizar uma reflexão sobre o poder. Para isso, cada ação tomada pelo príncipe será alvo de uma análise política do autor. Mahmood ul-Hasan (2005, p. 172) realizou uma pesquisa a fim de comparar as informações que Ibn al-Athīr relata sobre o próprio período com outras obras contemporâneas. Ele compara o Kāmil com algumas obras como o Kitāb al-Rawḍtayn de 'Abū Šāma, o al-Nawādir al-Sulțāniyah de Ibn Šadād, o Al-Fatḥ al-Qūsī fĩ al-fatḥ alQudsī , de 'Imād al-Dīn al-Isfahānī - considerado biógrafo oficial de Saladino - e o Kitāb Wafayāt al-'A'yān de Ibn Hallikān, e chega à conclusão que as informações contidas na obra de Ibn al-Athīr são idênticas a de seus contemporâneos. Mahmood considera que as pequenas variações encontradas são resultados da própria metodologia adotada pelo autor, isto é, o recolhimento de informações por testemunhos orais. Para ele, essas diferenças dizem muito mais respeito ao fato de nosso historiador depositar confiança nos testemunhos - muitas vezes impregnados pelos rumores e fofocas do povo - do que a uma prática impacial visando o elogio da dinastia dos atābegs.

Entretanto, esta explicação para as possíveis diferenças acaba legitimando uma falta de profissionalismo do historiador - no sentido da prática historiográfica - na análise de suas fontes, principalmente as orais, que poderiam ser facilmente comparadas a outras versões que provavelmente circulavam pelas cidades. Os críticos de Ibn al-Athīr deveriam levar em conta que as escolhas de um autor são consciêntes. O que não pode deslegitimar seu trabalho, porque seu pensamento representa as concepções de uma camada social, ou dinastia - como seriam todas as outras obras historiográficas - presente no contexto político do século XII/XIII.

Como dissemos antes ${ }^{55}$, o Kāmil é direcionado aos Príncipes. Neste sentido, a avaliação das atitudes Reais serão tomadas no âmbito da crítica política e moral - e no contexto contemporâneo a Ibn al-Athīr, da manuntenção do 'Islām - a fim de que, as posturas tomadas pelos Príncipes e as avaliações de suas consequências estejam claras ao leitor - sobretudo ao leitor Real, seu principal alvo - do que propriamente uma tomada de partido do autor. Assim, a opinião de Ibn al-Athīr sobre Saladino se daria a partir da análise política de suas posturas e ações, acompanhadas de críticas, elogios e, reverência ao caráter do sultão. São as decisões políticas e seus resultados que interessam ao autor, como ele demosntra nesta passagem:

Cada vez que ele se apoderava de uma cidade ou de uma fortaleza franca, como Acre, Ascalon, Jerusalém, Saladino permitia aos cavaleiros e soldados inimigos se exilar em Tiro, ainda que esta cidade se tivesse tornado praticamente

\footnotetext{
${ }^{54}$ Al- ta'rih al-bāhir fĩ al-dawla al-atābikya

${ }^{55}$ Supra, p. 07.
} 


\section{capítulo de dissertação}

invencível. Os francos do litoral enviaram mensagens àqueles que estão além dos mares, e estes últimos prometeram vir em seu socorro. Não deveriamos dizer que foi o próprio Saladino quem de algum modo organizou a defesa de Tiro contra seu próprio exército. (Ibn al-Athīr, apud Maalouf, 2007, p.192)

A crítica, aqui, é dada à estratégia militar e política de Saladino, ou seja, às suas ações enquanto governante e, principalmente, mujāhid ${ }^{56}$. Entretanto, ainda que criticasse as decisões de Saladino, Ibn al-Athīr reconhecia que "acima de todos ele era superior no exército e possuia muitas virtudes, realizando boas ações e foi um grande guerreiro contra os infiéis" (Ibn al-Athīr, apud Ul-Hasan, 2005, p. 173). Além de demonstrar imenso respeito ao sultão pela conquista de Jerusalém: "Essa nobre ação da conquista de Jerusalém só foi realizada, desde ' Umar ibn al-Hुațāāb, por Saladino. Este feito lhe basta para os títulos de gloria e honra" (Ibn al-Athīr, apud Micheau, 2007, p. 96). Ora, como a narrativa produzida é unívoca e não comporta as mais diferentes versões, como seus antecessores realizavam, as avaliações negativas acabam ganhando cores mais fortes, pois não possuem a versão oposta para balancear o julgamento. Desta forma, acima da posição política do autor, está presente, em sua narrativa, a avaliação das habilidades que o soberano deve ter para governar e se manter no poder.

Ibn al-Athīr realiza um trabalho de história universal, abarcando todos os povos e heranças regionais dos territórios islâmicos a fim de constituir e reiterar uma identidade muçulmana universal, isto é, que o espirito da comunidade muçulmana pudesse prevalecer em meio às numerosas dinastias e ameaças externas. Para isso, preocupa-se em tratar de cada período e cada região dando-lhes o mesmo grau de importância no relato dos eventos, colocando as diversas regiões em igualdade. Ao citar relatos de regiões e povos diferentes, Ibn al-Athīr já os valoriza, uma vez que utiliza como fonte para sua obra inclusive textos desprezados por todos os outros autores da época de que se têm notícia. Além disso, sua metodologia de trabalho, focada na construção de uma narrativa unívoca, afasta sua escrita das características do método tradicionalista de trabalho, que seguem com rigor as regras estabelecidas para transmissão das fontes - asānīd - e, principalmente, as regras analíticas de composição da obra, em que cada evento deve situar-se exatamente no espaço temporal em que ocorreu. 0 Kāmil, principalmente na porção relativa ao período contemporâneo do autor, não faz jus à classificação tradicionalista, apresentando uma narrativa mais livre das regras medotológicas que lhe seriam impostas pelo método tradicional a fim de fornecer ao leitor uma obra mais prazerosa, de fácil leitura e compreensão.

Finalmente, sua obra não se resume a uma compilação de historiografias. Ao contrário: é uma composição de uma nova narrativa, que se compromete com a avaliação política e com as responsabilidades humanas das ações, principalmente no que concerne à avaliação dos anos contemporâneos ao autor. Por isso, localizar Ibn alAthīr junto aos tradicionalistas seria negar todas as iniciativas e inovações críticas e

\footnotetext{
${ }^{56}$ Aquele que pratica o jihād.
} 


\section{capítulo de dissertação}

metodológicas que o autor realiza para enquadrá-lo num esquema que não o representa. Talvez, assim como al-Tabarī seja um dos principais autores que se afastam de uma velha historiografia - que servia à Sunna - e realizam um novo trabalho historiográfico - mais independente, até mesmo secular -, cabe a Ibn al-Athīr e ao Kāmil, um espaço de destaque entre os historiógrafos e a escrita da história dos árabes. Ibn al-Athīr representa, para a historiografia árabe, uma quebra de paradigmas, pois, como argumentamos, ele rompe com as rígidas regras de uma metodologia, cuja prática levava a textos de cunho compilatório, para oferecer uma nova historiografia, que, por sua vez, meditasse sobre suas fontes, realizando escolhas, análises, críticas e interpretações. De tal prática, temos uma obra que, a despeito das críticas contemporâneas, pode ser considerada original porque, em muitos sentidos, é única. Ademais, ela é fundamental para o estudo da reação muçulmana às Cruzadas e, principalmente, para a compreensão do discurso construído pelo autor através das características particulares do Kãmil - como sua universalidade - e a sua relação com os seus leitores no século XIII. 


\section{Referência Bibliográfica}

\section{Corpus Documental}

IBN AL ATHĪR. Al-Kamil fi al-Tarikh in Recueil des Historiens des Croisades. Historiens Orientaux. V. I. Paris, 1872 - 1906

IBN AL ATHĪR. IZZ AL DIN. The Chronicle of Ibn al Athir for the Crusading Period from al Kamil I l-ta-rikh. Part 2: The Years 541-589/1146/1193: the Age of Nur al Din and Saladin. Crusade Texts Translations, 15. Trad. D.S. Richards. Ashgate. Surrey, 2010

\section{Bibliografia de Apoio}

AL-AZMEH, Aziz. Histoire et narration dans l'historiographie arabe. In: Annales. Économies, Sociétés, Civilisations. 41e année, N.2, 1986. Pp. 411 - 431.

ALCORÃO. Tradução do sentido do Nobre Alcorão para a Língua Portuguesa. Trad. Helmi Nasr. Al-Madinah Al-Munauarah. Complexo do Rei Fahd.

ANÔNIMO. Livro das Mil e Uma Noites, Volume I: ramo sírio. (Introdução, notas, apêndices e tradução do árabe: Mamede Mustafa Jarouche). São Paulo: Globo, 2006.

ARAÚJO, Richard Max de. Ibn Khaldun: Idéia de Decadência dos Estados. São Paulo: Humanitas Editorial; Fapesp, 2007.

AVERROES. Le livre du discours décisif. Trad. Marc Geoffroy. GF Flamarion, 1996.

BENCHEIKH, Jamel Eddine. MIQUEL, André. D’Arabie et D'Islam. Paris: Éditions Odile Jacob, 1992.

CAHEN. Claude. L'Historiographie Arabe: Des Origines au VII s.H. In: Arabica. Tome 33, Fasc.2, (1986). pp. 133 - 198.

. Le Recueil des historiens des coisades. À propôs d'une réimpression anastatique. In: Journal des savants. 1970, N², pp. 94 - 104.

CARRA DE VAUX, Baron. Les Penseurs de L'Islam. Tome Premier: Les Souverains, L'Histoire et La Philosophie Politique. Paris: Librairie Paul Geuthner, 1921.

CHEDDADI, Abdesselam. A l'aube de l'historiographie arabo-musulmane: la mémoire islamique. In: Studia Islamica, Nº 74 (1991), pp. 29-41.

GABRIELI, Francesco. Chroniques arabes des Croisades. Tradução Viviana Pâques. Sindbad/ Actes Sud, 2001

Introduction aux historiens arabes des croisades. In: Cahiers de civilization médiévale. 13e année ( ${ }^{\circ}$ 51). Juillet-septembre 1970. pp. 221 - 228 
GABRIELI, Francesco. KHAN, M.S. Arabic Historiography. In. Islamic Studies. Vol. 18, No. 2 (Summer 1979) International Islamic University, Islamabad. pp. 81 - 95.

GIBB, H. A. R. Notes on the Arabic Materials for the History of Early Crusades. In: Bulletin of the School of Oriental Studies. University of London. Vol. 7, N 4 (1935), pp 739 - 754.

IBN ALMUQAFFA', Kalīla e Dimna. Org. Trad. Introdução e notas Mamede Mustafa Jarouche. São Paulo; Martins Fontes, 2005

LEVANONI, Amalia. “Atābak (atābeg)”, in: Encyclopaedia of Islam, THREE, Edited by: Kate Fleet, Gudrun Kramer, Denis Matringe, John Nawas, Everett Rowson. Consulted online on 23 September 2016. http://dx.doi.org/10.1163/1573-3912_ei3_COM_23689. First published online: 2010

MAALOUF, Amin. As Cruzadas vistas pelos Árabes. Trad. Pauline Alphene, Rogério Muoio. Revisão, José Carlos Sebe. São Paulo: Brasiliense, 2007.

MARTINEZ-GROS, Gabriel. MICHEAU, Françoise e TOUATI, Hourai. Chroniques Médiévales: Temps, Narration, Usages. [Introduction]. In: Studia Islamica. $N^{\circ}$ 104/105. Chroniques Medievales: Temps, Narration, Usages (2007), pp. 5 - 9.

MICHEAU, Françoise. Le Kitāb al kāmil fì l-tā'rīkh d'Ibn al-Athīr: Entre chronique et histoire. In: Studia Islamica. $N^{\circ} 104 / 105$. Chroniques Medievales: Temps, Narration, Usages (2007), pp. 81-101.

ROBINSON. Chase F. Islamic Historiography. Cambridge University Press, 2003.

ROSENTHAL, Franz. A History of a Muslim Historiography. Netherlands: E.J Brill. Leiden, 1968

TOUATI, Houari. Pour une histoire de la lecture au Moyen Âge musulman: à propôs des livres d'histoire. In: Studia Islamica. $N^{\circ}$ 104/105. Chroniques Medievales: Temps, Narration, Usages (2007), pp. 11-44.

UL-HASAN, Mahmood. Ibn al-Athīr. An Arab Historian. A Critical Analysis of HisTarikh al-Kamil and Tarikh al-Atabeca. New Delhi: Northern Book Centre, 2005

Texto recebido em: 15 de Dezembro de 2016 Aprovado em: 24 de Março de 2017 